\title{
ONTPLOOIINGSMOONTLIKHEDE VAN DIE KIND TEN OPSIGTE VAN OUER-KIND-VERBONDENHEID
}

MEV E WILLIAMS Dosent, Departement Verpleegkunde, UOVS

\section{INLEIDING}

Die ontplooiingsmoontlikhede van die kind word direk deur die moeder, asook die vader, se ervaring van die gebeure om die voortplantingsiklus beïnvloed.

Die geboorte van 'n baba is 'n gesinsgebeurtenis en daarom is kraamverpleging 'n gesingesentreerde praktyk. Deur 'n positiewe ouer-kind-verbondenheid of binding te bewerkstellig, lewer die verpleegkundige ' $n$ belangrike bydrae tot optimale ontwikkeling van die baba as unieke individu binne gesinsverband.

Om hierdie doel te bereik, word die geleidingsgebeure in drie fases verdeel: swangerskap, baring en die hantering van die baba tot op ongeveer ses weke.

\section{SWANGERSKAP}

Die doel van gesingesentreerde voorgeboortelike voorbereiding is om die swanger vrou en haar eggenoot fisies en geestelik vir die optimale hantering van swangerskap, baring, die nageboorte periode en die nuwe baba voor te berei. Deur die betrokkenheid en belangstelling van ouerpare in al hierdie fases van die voortplantingsiklus word die besef van die waardigheid, en die geestelike voordele, van 'n sterk gesinseenheid veskerp. Die toekomstige ouerpaar raak opgewasse teen die fisiese en psigiese stres wat

Hierdie referaat is gelewer tydens 'n werkseminaar oor die voorkoming van probleme by kinders, aangebied deur dosente van die Departemente Teologie, Verpleegkunde, Maatskaplike Werk en Opvoedkunde aan die Universiteit van die Oranje-Vrystaat. swangerskap en baring inhou. Nog 'n uitvloeisel van doeltreffende voorgeboortelike voorbereiding is 'n dieper verinniging en verryking van die huwelikslewe, asook geestelike en emosionele volwassenheid.

Deur menslikheid en welwillendheid, genaakbaarheid en toeganklikheid stel die verpleegkundige haar tot diens en bevorder die gesondheid van moeder, vader en kind.

Deur fisiese voorgeboorte-voorbereiding, inligting en advies oor swangerskap en baring, sowel as oor kinderopvoeding, speel die verpleegkundige ' $n$ kardinale rol as voorbereidingsagent in haar steungewing aan die gesin ten einde die potensiële krisisse van ouerskap te oorkom.

Gereelde fisiese oefeninge vir swanger vroue bestaan uit twee kategorieë:

- spieroefeninge om die liggaam fisies voor te berei vir baring; en

- doelbewuste ontspanning of gekontroleerde neuromuskulêre oefening om die pyn van 'n kontraksie te kan hanteer.

Verder dra dit tot die voorkoming van moederlike uitputting en ook fisiologies-psigologiese prikkelbaarheid tydens baring by.

Volgens Cohen ervaar 85 persent van alle vroue intense konflik gedurende hulle eerste swangerskap. Dit kan aan verskeie redes toegeskryf word, byvoorbeeld ekonomiese redes, frustrasie van onvervulde ambisie(s), liggaamlike veranderinge en onverklaarbare wisselinge in gemoedstemming. In die moderne, hoogs-geïndividualiseerde en geïndustrialiseerde samelewing waarin 'n gees van saaklikheid, nuttigheid en winsbejag die hoogste norm geword het, moet die

\section{SUMMARY}

By encouraging positive parent-child bonding the nurse makes an important contribution to the optimal development of the child. The nurse must provide support in pregnancy, labour and the management of the newborn.

verpleegkundige goeie interpersoonlike kommunikasie handhaaf en sinvolle bemoeienis maak met hierdie vrou Die verpleegkundige moet die swanger vrou emosioneel ondersteun, haar help om haar waardigheid te behou, tyd inruim om na haar te luister, waardering hê vir wat sy sê, voel of doen, en bereid wees om by haar te bly wanneer sy oorweldig voel deur haar ervaring van swangerskap.

In die tweede trimester van swangerskap ontwikkel 'n positiewe ingesteldheid teenoor die swangerskap en die vrou ervaar emosies van trots en moederliefde. Hierdie positiewe belewenis kan hoofsaaklik toegeskryf word aan fetale beweging wat sy voel en ' $n$ verbetering in haar algemene toestand. In hierdie stadium begin die moeder ' $n$ verbondenheid met die baba te ontwikkel en moet die verpleegkundige hierdie tyd nuttig gebruik om die ouer-kind verhouding te versterk.

In die derde trimester van swangerskap ervaar die swanger vrou 'n gevoel van ambivalensie en die verpleegkundige speel 'n belangrike rol in die geestelike ondersteuning van beide ouers. Met positiewe hantering van hierdie stadium, ontwikkel 'n nuwe faset in die ouerpaar se verhouding, naamlik ouerskap, en die huweliksband word verinnig en versterk.

Net soos die swanger vrou fisies, psigies en emosioneel vir die voortplantingsiklus voorberei moet word, net so belangrik is dit dat die man die nodige voorbereiding kan 
bekom ten einde sy vrou se veranderde behoeftes, haar angs en vrese en haar drome en ideale te begryp en te waardeer. Hy word nou in die posisie gestel om sy lewensmaat met insig by te staan en kry ook 'n groter deelname en erkenning.

In die tweede trimester kan die vader werklik vir die eerste keer met die fisiese aspek van swangerskap identifiseer deur die fetale beweging waar te neem.

Net soos die swanger vrou ervaar die man angsgevoelens aangaande die naderende baring en geboorte. Feitelike, emosionele en geestelike voorgeboortelike voorbereiding is essensieel vir die "nuwe" vader. As hy by sy vrou in die kraamkamer is, sal sinvolle voorbereiding hom in staat stel om die nodige ondersteuning aan sy vrou te gee en sodoende 'n positiewe bydrae tot die geboorte van hul baba te lewer.

Deur voorligting en advies oor die behoeftes van die vrou in die nageboorte-tydperk, die noodsaaklikheid van vroeë vader-baba-interaksie en kontak, en ook versterking van sy selfvertroue, kan dit sy funksie en rolmodel as vader net versterk.

Die krisisse wat ouerpare tydens swangerskap kan beleef, word deur vele en komplekse faktore veroorsaak. Van die belangrikste hier is byvoorbeeld disekwilibrium tussen huweliksmaats, die enkelouer, die adolessente ouer, onbeplande swangerskap, emosionele labiliteit by een of albei ouers. Sodra 'n potensiële probleem deur die verpleegkundige of ' $n$ ander spanlid gediagnoseer word, moet die professionele verpleegkundige haarself terapeuties gebruik deur haar kennis en persoonlikheid doelbewus aan te wend om doeltreffende oplossing en hantering van die situasie te verseker.

\section{BARING}

In die Republiek van Suid-Afrika vind die meeste geboortes van Blanke babas in hospitale plaas. Hospitalisasie beteken vir die vrou in baring 'n tydelike prysgawe van die warmte en gemoedsekerheid van haar vertroude leefwêreld.
Elke kraamvrou moet tydens baring met 'n positiewe gesindheid en 'n liefdevolle medemenslikheid deur die verpleegkundige versorg word. Depersonalisasie van die vrou in baring moet voorkom word deur geïndividualiseerde professionele verpleegsorg en nie bloot tegniese taakverrigting nie.

Die verpleegkundige moet sorg dat die pasiënt op die regte tydstip tydens baring voldoende pynverligting en sedasie ontvang. Daardeur word onnodige trauma voorkom en die fisiologiese voordele van pynverligting is belangrik vir moeder en baba. Die pasiënt mag nooit tydens baring alleen gelaat word nie, en die eggenoot word aangemoedig om by sy vrou te bly. Die voorbereide eggenoot kan sy vrou aanmoedig om psigoprofilakse vir die pyn van die kontraksies toe te pas deur spesifieke asemhaling te doen.

In 'n ondersoek wat plaaslik uitgevoer is, het $25 \%$ van 166 vroue baring as uiters traumaties en negatief ervaar as gevolg van pyn. Van hierdie $25 \%$ het $13,25 \%$ dit toegeskryf aan pyn per se. Die res het gesê dat die pynverdowing te laat toegedien was en hulle sodoende ook nie aktief tydens die geboorte van die baba kon saamwerk nie omdat die pynmiddel hulle slaperig en deurmekaar gemaak het. Hierdie vroue het ongelukkig gevoel omdat hulle voel dat hulle misluk het in dit waarvoor hulle hulself so lank voorberei het.

Die logiese optrede deur die verpleegkundige ten opsigte van pynverligting tydens baring is dat pynstillers volgens die pasiënt se behoeftes toegedien moet word en nie volgens die teoretiese voorskrifte of roetine-idees van die verpleegkundige of geneesheer nie.

Tydens baring en die werklike geboorte van die baba, moet die ouers geestelik en fisies deur die verpleegkundige ondersteun word. Hulle angs moet verlig word sodat beide ouers die geboorte van die baba as 'n positiewe ervaring beleef. Indien dit as traumaties of negatief ervaar word, het dit 'n remmende invloed op die ouer-kind-verbondenheid en is dit 'n saadjie wat gesaai is wat later tot emosionele deprivasie of selfs fisieke kindermishandeling kan lei. Die baba word dan as oorsaak vir die moeder se pyn gesien en sy ondervind sterk gevoelens om haarself op die baba te wreek.

Om die ouer-kind-verbondenheid te versterk, veral in hoë risikogevalle, moet die verpleegkundige definitiewe hulp aan die ouers verleen. Vir ongeveer een uur na geboorte is die baba wakker en aktief - sy ogies is oop, hy reageer op stemme sowel as aanraking en is in staat om aan die moeder se bors te suig. Die oorgrote meerderheid van moeders wil graag nou die baba vashou en na hom kyk. Hospitaalroetine veroorsaak dikwels probleme in hierdie fase.

Ten einde ouer-kind-verbondenheid te bevorder, moet die ouers aangemoedig word om die baba aan te raak, hom te vertroetel, oogkontak te maak en met die baba te gesels. Dit is noodsaaklik dat die ouers terugvoer van hulle baba moet ontvang in reaksie op hulle versorging en vertroeteling. Hierdeur ontwikkel intieme verbondenheid tussen die ouers en die baba. Wanneer die baba na sy moeder se oë kyk, of as hy beweeg in reaksie op haar versorging, stil en rustig word of gedrag openbaar wat bewys dat hy haar bemoedering waardeer, versterk dit die moeder se gevoel van gehegtheid en verbondenheid met haar baba. Moederliefde en ook vaderliefde word op dié wyse positief versterk

Deur die moeder te motiveer om borsmelk aan haar baba te verskaf, voel die moeder dat sy 'n daadwerklike bydrae maak tot die baba se versorging en welsyn. Borsvoeding moet egter nie geforseer word teen die moeder se wil nie. Indien bottelvoeding gegee word, moet die moeder ingelig word oor die noodsaaklikheid daarvan om die baba teen haar vas te hou en self die bottelvoeding te gee.

Probleme met bemoedering en bevadering word deur vele faktore veroorsaak, byvoorbeeld voortydse baring met 'n gevolglike voortydse baba, kongenitale abnormaliteite by die baba en probleme van ouers soos reeds genoem, byvoorbeeld die enkelouer, die adolessente ouer.

(Vervolg op p. 29) 